\title{
PLAINS $\mathrm{CO}_{2}$ REDUCTION PARTNERSHIP
}

\author{
Quarterly Technical Progress Report
}

(for the period April 1-June 30, 2005)

Prepared for:

AAD Document Control

U.S. Department of Energy

National Energy Technology Laboratory

PO Box 10940, MS 921-107

Pittsburgh, PA 15236-0940

Agreement No. DE-PS26-03NT41982

Contracting Officer's Representative: John Litynski

Prepared by:

Edward N. Steadman John A. Harju Erin M. O’Leary James A. Sorensen Daniel J. Daly Melanie D. Jensen Lisa S. Botnen

Energy \& Environmental Research Center University of North Dakota PO Box 9018

Grand Forks, ND 58202-9018

July 2005 


\section{DISCLAIMER}

This report was prepared as an account of work sponsored by an agency of the United States Government. Neither the United States Government, nor any agency thereof, nor any of their employees makes any warranty, express or implied, or assumes any legal liability or responsibility for the accuracy, completeness, or usefulness of any information, apparatus, product, or process disclosed or represents that its use would not infringe privately owned rights. Reference herein to any specific commercial product, process, or service by trade name, trademark, manufacturer, or otherwise does not necessarily constitute or imply its endorsement, recommendation, or favoring by the United States Government or any agency thereof. The views and opinions of authors expressed herein do not necessarily state or reflect those of the United States Government or any agency thereof.

This report is available to the public from the National Technical Information Service, U.S. Department of Commerce, 5285 Port Royal Road, Springfield, VA 22161; phone orders accepted at (703) 487-4650.

\section{EERC DISCLAIMER}

LEGAL NOTICE This research report was prepared by the Energy \& Environmental Research Center (EERC), an agency of the University of North Dakota, as an account of work sponsored by the U.S. Department of Energy and the North Dakota Industrial Commission. Because of the research nature of the work performed, neither the EERC nor any of its employees makes any warranty, express or implied, or assumes any legal liability or responsibility for the accuracy, completeness, or usefulness of any information, apparatus, product, or process disclosed, or represents that its use would not infringe privately owned rights. Reference herein to any specific commercial product, process, or service by trade name, trademark, manufacturer, or otherwise does not necessarily constitute or imply its endorsement or recommendation by the EERC. 


\title{
PLAINS $\mathrm{CO}_{2}$ REDUCTION PARTNERSHIP
}

\begin{abstract}
The Plains $\mathrm{CO}_{2}$ Reduction (PCOR) Partnership characterization work is nearing completion, and most remaining efforts are related to finalizing work products. Task 2 (Technology Deployment) has developed a Topical Report entitled "Deployment Issues Related to Geologic $\mathrm{CO}_{2}$ Sequestration in the PCOR Partnership Region.” Task 3 (Public Outreach) has developed an informational Public Television program entitled "Nature in the Balance," about $\mathrm{CO}_{2}$ sequestration. The program was completed and aired on Prairie Public Television in this quarter. Task 4 (Sources, Sinks, and Infrastructure) efforts are nearing completion, and data regarding $\mathrm{CO}_{2}$ sources and sinks and data on the performance and costs for $\mathrm{CO}_{2}$ separation, capture, treatment, and compression for pipeline transportation are being incorporated into a series of topical reports. The expansion of the Decision Support System Geographic Information System database has continued with the development of a "save bookmark" feature that allows users to save a map from the system easily. A feature that allows users to develop a report that summarizes $\mathrm{CO}_{2}$ sequestration parameters was also developed. Task 5 (Modeling and Phase II Action Plans) focused on screening and qualitatively assessing sequestration options and developing economic estimates for important regional $\mathrm{CO}_{2}$ sequestration strategies.
\end{abstract}





\section{TABLE OF CONTENTS}

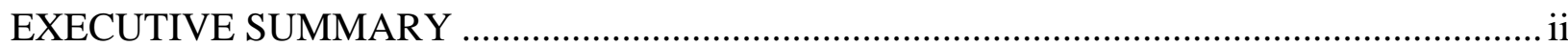

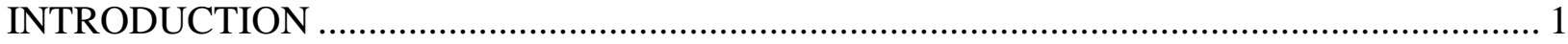

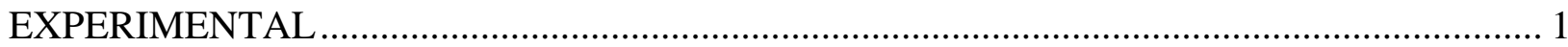

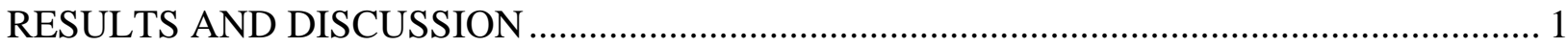

Task 1 - Management, Reporting, and Technical Outreach........................................................ 1

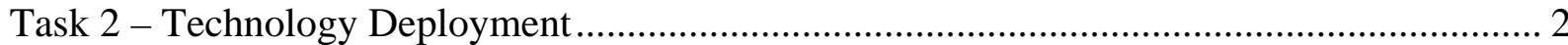

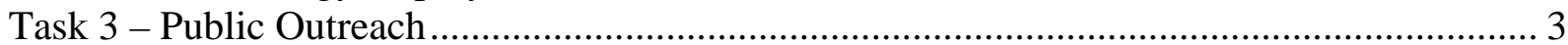

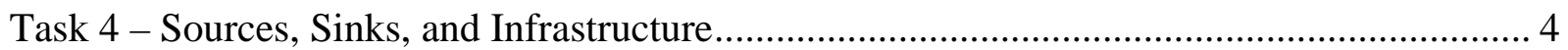

Subtask 4.1 - Task Management ..................................................................................... 4

Subtask 4.2 - Characterization of PCOR Partnership Regional $\mathrm{CO}_{2}$ Sources ........................ 4

Subtask 4.3 - Characterization of PCOR Partnership Regional $\mathrm{CO}_{2}$ Sinks ............................ 5

Subtask 4.4 - PCOR Partnership Information Systems .......................................................... 7

Task 5 - Modeling and Phase II Action Plans............................................................................. 7

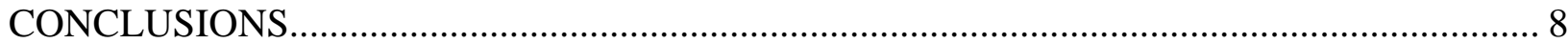

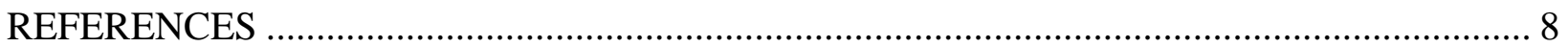

POWERPOINT PROJECT SUMMARY …………….................................................Appendix A 


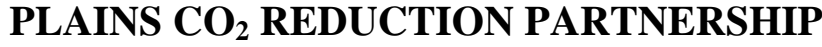

\section{EXECUTIVE SUMMARY}

The Plains $\mathrm{CO}_{2}$ Reduction (PCOR) Partnership is nearing the completion of its goals and objectives. The goals and objectives include the following: 1 ) developing information regarding $\mathrm{CO}_{2}$ sequestration deployment issues; 2) providing information to be used to assess $\mathrm{CO}_{2}$ sequestration opportunities in the PCOR Partnership region; 3) developing an informational Public Television program about $\mathrm{CO}_{2}$ sequestration; 4) developing additional outreach tools to better inform the public with respect to $\mathrm{CO}_{2}$ sequestration; 5) collection of data regarding $\mathrm{CO}_{2}$ sources and sinks and data on the performance and costs for $\mathrm{CO}_{2}$ separation, capture, treatment, and compression for pipeline transportation; and 6) screening and qualitatively assessing sequestration options. Activities in this and the next quarter are focused on finalizing topical reports and other required work products. 


\section{PLAINS $\mathrm{CO}_{2}$ REDUCTION PARTNERSHIP \\ Quarterly Technical Progress Report \\ April 1-June 30, 2005}

\section{INTRODUCTION}

As one of seven Regional Carbon Sequestration Partnerships (RCSPs), the Plains $\mathrm{CO}_{2}$ Reduction (PCOR) Partnership is identifying practical $\mathrm{CO}_{2}$ sequestration options for the PCOR Partnership region. The PCOR Partnership is characterizing the technical issues, enhancing the public's understanding of $\mathrm{CO}_{2}$ sequestration, identifying the most promising opportunities for sequestration in the region, and detailing an action plan for the demonstration of regional $\mathrm{CO}_{2}$ sequestration opportunities. As a result of Phase I efforts, several field validation tests have been selected to facilitate and manage the demonstration and deployment of $\mathrm{CO}_{2}$ sequestration projects. This report summarizes the activities for this reporting period. The activities are organized into five tasks: 1) Task 1 - Management, Reporting, and Technical Outreach;

2) Task 2 - Technology Deployment, which is evaluating technology deployment and regulatory issues and developing Phase II action plans; 3) Task 3 - Public Outreach, which is raising public awareness regarding $\mathrm{CO}_{2}$ sequestration and providing input for potential Phase II action plans;

4) Task 4 - Sources, Sinks, and Infrastructure, which is compiling and assessing information on sources, sinks, and options for $\mathrm{CO}_{2}$ separation and transportation and developing relational and geographic information system (GIS) databases for housing these data; and 5) Task 5 - Modeling and Phase II action plans, which is systematically and objectively identifying promising $\mathrm{CO}_{2}$ sequestration options using screening tools and a model.

\section{EXPERIMENTAL}

Phase I of the PCOR Partnership project is designed to identify promising $\mathrm{CO}_{2}$ sequestration options for our region. Until the sequestration options are identified and the most promising near-term options are selected, experimental activities will not take place. The experimental portion of this program is scheduled for the U.S. Department of Energy's (DOE's) Phase II RCSP program.

\section{RESULTS AND DISCUSSION}

\section{Task 1 - Management, Reporting, and Technical Outreach}

Task 1 for this reporting period focused on the following activities:

- Managing overall project activities.

- Informing stakeholders about DOE's Regional Partnership program and the PCOR Partnership. 
- Adding new partners to the PCOR Partnership.

- Discussing potential Phase II demonstration activities with prospective Phase II participants.

The PCOR Partnership program participated in and/or presented at the following meetings:

- 2005 International Water Conference, Winnipeg, Manitoba, Canada (April)

- 13th Williston Basin Petroleum Conference, Regina, Saskatchewan, Canada (April)

- “New Natural Gas,” Interstate Oil and Gas Compact Commission Midyear Issues Summit, Anchorage, Alaska (May)

- Carbon Sequestration Leadership Forum Stakeholder Briefing, Alexandria, Virginia (May)

- Fourth Annual Conference on Carbon Capture and Separation, Alexandria, Virginia (May)

- Meeting with North Dakota Petroleum Council (NDPC), Bismarck, North Dakota (June)

- American Association of Petroleum Geologists 2005 Annual Convention - Exploring Energy Systems, Calgary, Alberta, Canada (June)

- Meeting with Ducks Unlimited, Inc., U.S. Geological Survey, and Ducks Unlimited Canada, Bismarck, North Dakota (July)

Materials presented at these meetings were sent to the DOE Contracting Officer's Representative (COR) under separate cover.

Minnesota Power joined the PCOR Partnership this quarter.

\section{Task 2 - Technology Deployment}

The goal of Task 2 is to identify and resolve sequestration deployment issues for the PCOR Partnership region, including 1) safety, regulatory, and permitting requirements; 2) public perceptions; 3) ecosystem impacts; and 4) monitoring, measurement, and verification (MM\&V) requirements. Activities conducted during this reporting period included 1) further development of measurement, mitigation, and verification strategies for potential geologic and terrestrial carbon storage opportunities in the PCOR Partnership region; 2) finalizing the topical report entitled "Deployment Issues Related to Geologic $\mathrm{CO}_{2}$ Sequestration in the PCOR Partnership Region”; 3) facilitating preparation of a draft Phase II action plan; and 4) participation in monthly internal PCOR Partnership management and general meetings. 
Future activities include reviewing the development of MM\&V strategies for potential sequestration options in the PCOR Partnership region.

\section{Task 3 - Public Outreach}

Public education and outreach for this reporting period included 1) involvement in PCOR Partnership and RCSP program meetings and conference calls as appropriate; 2) the continued review of critical background documents, particularly those focused on gauging public opinion regarding sequestration and communicating risk; 3) updating the public Web site (www.undeerc.org/pcor) as appropriate; 4) development of fact sheets; 5) continued progress on the 30-minute general audience information video; 6) continued progress on outreach research activities; and 7) activities that support DOE’s partnership program effort.

Task 3 personnel took part in activities to support RCSP outreach and the program. These activities included 1) taking part in monthly RCSP program outreach conference calls (chaired by Sarah Forbes, National Energy Technology Laboratory [NETL]); 2) contributing to the paper and presentation (Sarah Wade, Keystone, Center for Science \& Public Policy, lead author) for the Alexandria, Virginia, conference on partnership outreach; and 3) providing information to support the fall 2005 Programmatic Environmental Impact Statement hearing in the region.

Other outreach activities included the following:

- $\quad$ Completed Fact Sheet No. 2 (sequestration background) and No. 3 (Weyburn project) and submitted the products to NETL for review.

- Made updates as needed to the public Web site.

- Held two focus groups on the PCOR Partnership video entitled, "Nature in the Balance - $\mathrm{CO}_{2}$ Sequestration” in Williston, North Dakota, in mid-April as part of the public opinion activities. The Williston area was chosen for the focus groups because of its potential for both geologic and terrestrial sequestration activities. The materials for use in the focus groups were reviewed by NETL in late March, the focus group participants were recruited in early April by Energy \& Environmental Research Center (EERC) personnel, the focus groups were held on April 21 and 22 (the proceedings were videotaped), and the topical report was completed in June 2005.

- Completed and distributed newspaper articles regarding general, terrestrial, and geologic sequestration (and announcing the broadcast of the PCOR Partnership sequestration video) to regional papers in late April. The pieces were run in a number of newspapers in the region in early May.

- Resumed work on the education materials. The education materials are scheduled for completion in the summer of 2005.

- Completed and broadcast the PCOR Partnership general audience video (Nature in the Balance $-\mathrm{CO}_{2}$ Sequestration). Details include the following: 
- The video editing was completed in March following a review by NETL. Closed captioning (required for broadcast by Public Television) was completed in early April, and a broadcast date of May 12 was set and included in the May program guide for Prairie Public Television.

- The cover design for the DVD of the program was completed in April, and the DVDs were ordered, produced, and packaged in April. The DVDs will be shipped in July 2005.

- The video was broadcast on Prairie Public Television on May 12 at 8:30 p.m. The broadcast was available to approximately 520,000 households in the central portion of the PCOR Partnership region. The broadcast was announced to partners by e-mail and to the public through PCOR Partnership newspaper articles, news releases, and in the monthly Prairie Public Television Viewer's Guide.

- The video was previewed at the NETL booth at the Fourth Annual Conference on Carbon Capture and Separation in Alexandria, Virginia, in early May.

\section{Task 4 - Sources, Sinks, and Infrastructure}

\section{Subtask 4.1 - Task Management}

Activities under Subtask 4.1 focused on organizing working groups, assigning specific tasks enumerated under the project work plan and preparing materials for meetings. The collection and cataloging of relevant literature into the reference manager system continued. Key meetings with partners that required travel included the following:

- Met with Stefan Bachu of Alberta Energy and Utilities Board in Calgary to discuss nature and progress of deliverables.

- Met with Husky Energy in Calgary, Alberta, to discuss the potential for Husky's participation in Phases I and II.

- Met with Apache Canada, Ltd., in Calgary, Alberta, to discuss proposed Phase II activities at Apache's acid gas injection site near Zama, Alberta.

\section{Subtask 4.2 - Characterization of PCOR Partnership Regional $\mathrm{CO}_{2}$ Sources}

Subtask 4.2 primarily focused on refining the collection of readily available $\mathrm{CO}_{2}$ source data for the states and provinces in the PCOR Partnership region. Most data were obtained or mathematically derived from the U.S. Environmental Protection Agency's e-GRID and Technology Transfer Network databases. 


\section{Subtask 4.3 - Characterization of PCOR Partnership Regional $\mathrm{CO}_{2}$ Sinks}

Subtask 4.3 continued with the acquisition, evaluation, and refinement of data on the geological sinks in the PCOR Partnership region. Significant accomplishments were made toward the development and implementation of a method to quantify the $\mathrm{CO}_{2}$ storage capacity of carbon sequestration units in the region. Data sets and maps were refined to develop sequestration capacity estimates for the Newcastle Formation and the Inyan Kara Group, which are Cretaceous-age sandstone formations that constitute major saline aquifers in the northern Great Plains. Data sets and maps for the Viking Formation, which is the equivalent of the Newcastle Formation in Alberta, Saskatchewan, and Manitoba, were also compiled and integrated for the purpose of developing sequestration capacity estimates for the Cretaceous system in the Western Canadian Sedimentary Basin.

\section{Subtask 4.3.1 - Evaluation of Alternative Agricultural and Management Practices}

Spring field preparatory work was conducted at the North Dakota State University (NDSU) Hettinger Research Extension Center (HREC) research plots.

With reference to the agricultural component, all activities were focused on the completion of reports. Work was done to finalize a draft topical report analyzing the economic potential for soil carbon sequestration in southwestern North Dakota. Work was also done on a second paper that represents an extensive review of literature addressing the economic potential for terrestrial sequestration based on agriculture, forestry, and related land use changes. The scope of the review is nationwide, but with special emphasis on the PCOR Partnership region.

\section{Subtask 4.3.2 - Carbon Sequestration in Wetlands}

U.S. Geological Survey (USGS) and Ducks Unlimited Canada (DUC) partners continued development of the PCOR Partnership prairie wetland carbon sequestration database for estimating the potential of prairie wetlands to sequester atmospheric carbon.

The following presentations and meetings were conducted as part of Subtask 4.3.2:

- April 7, 2005: Robert Gleason (USGS) coordinated a session on carbon sequestration at the Red River Basin Institute Second Annual International Water Conference, April 67, 2005, Winnipeg, Manitoba, Canada. The session included the following presentations:

- Impact of Wetland and Grassland Restoration Programs in the Prairie Pothole Region on Carbon Sequestration and Greenhouse Gas Emissions. Robert Gleason and Ned H. Euliss, Jr., USGS, Northern Prairie Wildlife Research Center, Jamestown, North Dakota

- The Role of Prairie Wetlands as Carbon Sinks within the Agricultural Landscape. R.L. McDougal, H.R. Murkin, R.G. Clark, and R. Bourbonniere. DUC, Stonewall, Manitoba; Canada Wildlife Service, Environment Canada, Saskatoon, 
Saskatchewan; Aquatic Ecosystem Impacts Branch, Environment Canada, Burlington, Ontario.

— Establishing a Baseline for Soil Organic Carbon on the Glacial Ridge Restoration Project. Timothy Amundson and David Hopkins, Department of Soil Science, North Dakota State University, Fargo, North Dakota.

- The Plains $\mathrm{CO}_{2}$ Reduction Partnership: Developing $\mathrm{CO}_{2}$ Sequestration Opportunities in the North American Great Plains. Edward N. Steadman and John A. Harju, EERC, Grand Forks, North Dakota.

- April 14, 2005: Robert Gleason and Kevin Kermes (USGS) met with EERC staff to discuss technical issues for development of a regional database to estimate carbon storage potential of restorable wetlands in the PCOR Partnership region.

- May 5, 2005: Robert Gleason traveled to Washington, DC, May 2-6, to attend DOE's Annual Carbon Sequestration Symposium and also to present two papers at a 1-day meeting on May 5, hosted by the U.S. Department of Agriculture (USDA) Natural Resources Conservation Service (NRCS) that focused on the NRCS Conservation Effects Assessment Program (CEAP) for wetlands. Talks presented by Mr. Gleason were entitled "Prairie Pothole Regional Assessment: Impact of U.S. Department of Agriculture and Department of Interior Programs on Ecological Services Derived from Restored Prairie Wetlands and Adjacent Grasslands" and "Working Toward a Temporal Model to Assess and Quantify the Ecosystem Services Provided by USDA and U.S. Department of Interior (DOI) Conservation Programs.”

- May 15, 2005: Robert Gleason traveled to Denver, Colorado, on June 14-16 to attend a USGS science workshop entitled “Environmental Effects of Agricultural Practices.” He presented a paper entitled, "Overview of Wetland Evaluations in the Northern Great Plains.”

- May 19, 2005: Robert Gleason and Kevin Kermes (USGS) met with research scientists from the USGS Earth Resources Observation \& Science (EROS) Data Center. EROS Scientists attending the meeting included Larry Tieszen, Norman Bliss, Shuguang Liu, Bruce Wylie, and Chris Wright. The meeting was held at NPWRC and explored mutual research interests and potential future collaborations.

Mr. Gleason gave the following presentations: 1) "Working Towards a Temporal Model to Assess and Quantify the Ecosystem Services Provided by USDA and DOI Conservation Programs” and 2) "A Prairie Pothole Regional Assessment: Impacts of USDA and U.S. DOI Programs on Ecological Services Derived from Restored Prairie Wetlands and Adjacent Grasslands.”

Larry Tieszen presented an overview of EROS carbon science activities. Norman Bliss gave a presentation entitled "Soil Organic Carbon Estimates from NRCS databases: the Wetland Contribution.” 
Bruce Wylie presented research on "Scaling up Carbon Fluxes and Climatic Anomaly Detection."

Shuguang Liu presented “Biogeochemical Modeling in the GEMS Framework,” and Chris Wright presented "Remote Sensing of Palustrine Wetlands in Yellowstone National Park.”

- June 27, 2005: Robert Gleason (USGS) gave a presentation to the North Dakota Farmers Unions on the potential of prairie wetlands to sequester carbon.

- Rhonda L. McDougal gave a talk entitled "Exploring Carbon Sequestration of Prairie Wetland Landscapes” at the Halifax 2005: Building Bridges - Across Science, Through Time, Around the World - Canadian Society of Soil Science Annual Meeting, May 1518, 2005.

\section{Subtask 4.4 - PCOR Partnership Information Systems}

The GIS portion of the PCOR Partnership Decision Support System (DSS) was enhanced with the following new tools and reports.

Save Bookmark Users can now save a map by clicking on Save Bookmark in the top right corner of the map window. This will bring up a form for the user to name and save the current map to their Favorites folder for retrieval at a later date. For more information on how to use the Favorites feature, the user can click on the GIS Help link. The Favorites feature is only available for the Internet Explorer browser.

Field-Pool Reports The report that is displayed when the user selects a specific field has been modified to display a summary of parameters used in the $\mathrm{CO}_{2}$ sequestration estimations near the top of the report for each field and pool.

The DSS staff from the EERC met with the USGS and NDSU staff to discuss the integration of terrestrial data into the GIS site. The EERC developed screen shots of how the $\mathrm{CO}_{2}$ estimates for terrestrial data will be displayed within the DSS and will begin programming in July 2005.

The EERC participated in several working group conference calls. These calls were mainly focused on the NATCARB Web site.

\section{Task 5 - Modeling and Phase II Action Plans}

During the April-June 2005 quarter, a spreadsheet tool developed by project personnel as part of the economic calculations was used to estimate the cost of retrofitting existing lignitefired PCOR Partnership power plants with either amine-scrubbing or oxygen combustion technologies. Capture costs were estimated to be about $\$ 23$ and $\$ 32 /$ ton $\mathrm{CO}_{2}$ for amine scrubbing and oxygen combustion, respectively. Avoided costs were estimated at $\$ 35 /$ ton $\mathrm{CO}_{2}$ for amine scrubbing and \$55/ton for oxygen combustion. By comparison, the cost of capture by amine 
scrubbing at a refinery complex has been estimated to be $\$ 45-\$ 54 /$ ton $\mathrm{CO}_{2}(1)$. This information was included in the Carbon Separation and Capture topical report prepared as part of Task 4.

Details about the region's $\mathrm{CO}_{2}$ sources were gathered from the modeling spreadsheets and used to prepare the $\mathrm{CO}_{2}$ Source Characterization of the PCOR Partnership Region topical report.

Preliminary economic estimations were begun for the important regional strategies that have been proposed for demonstration during Phase II. These calculations will be incorporated into the topical report about the identification of $\mathrm{CO}_{2}$ sequestration strategies in the PCOR Partnership region that will be prepared during the July-September quarter.

Close communication with the other PCOR Partnership task leaders continued during this quarter. These discussions ensured that the activities performed in the other tasks support the model and action plan development.

Future Task 5 activities include the following:

- Completing the economic estimations for the important regional strategies that have been proposed for demonstration during Phase II.

- Preparing a topical report describing the matching and screening protocol, the results of the matching system beta check, the preliminary economic calculations of the sequestration process as applied to the most promising regional strategies, and the final regional results for Phase I.

\section{CONCLUSIONS}

Phase I efforts of the PCOR Partnership are nearing completion. Most of the sink and source characterization work is complete. Developing final work products in the form of topical reports, fact sheets, videos, etc., is the focus of efforts at this point. Task 5 efforts are now focused on completing economic estimations for important regional strategies that have been proposed for demonstration during Phase II.

\section{REFERENCES}

1. Simmonds, M. et al. A Study of Very Large Scale Post Combustion $\mathrm{CO}_{2}$ Capture at a Refining and Petrochemical Complex. Presented at the 6th Annual Greenhouse Gas Technology Conference, Kyoto, Japan, Oct 2003. 


\section{POWERPOINT PROJECT SUMMARY}

APPENDIX A 


\title{
University of North Dakota
}

Energy \& Environmental Research Center

Plains $\mathrm{CO}_{2}$ Reduction Partnership

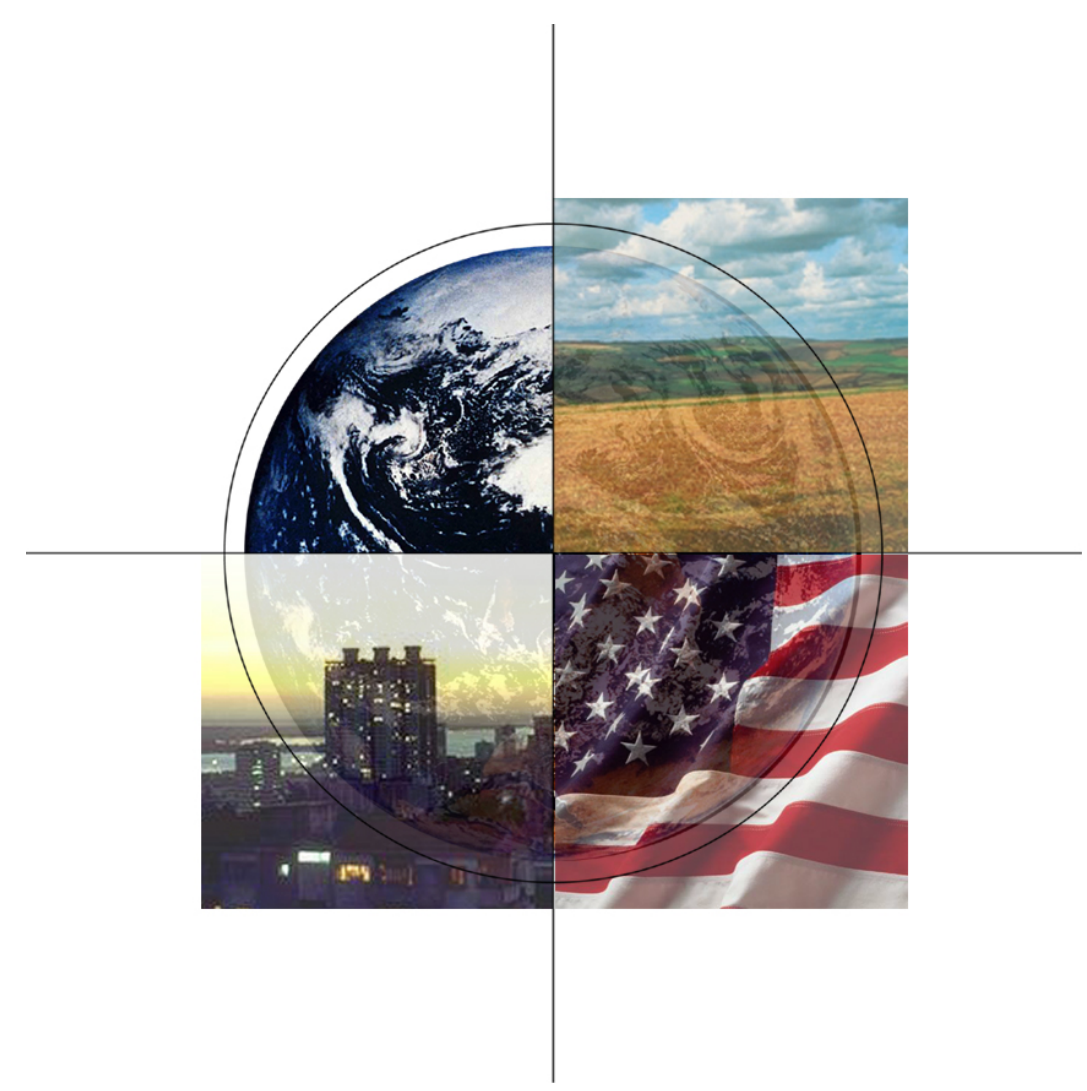

\author{
Project Summary \\ DE-PS26-O3NT41982
}

Last Updated: March 28, 2005

National Energy Technology Laboratory 


\section{Partnership Objectives}

The Plains $\mathrm{CO}_{2}$ Reduction (PCOR) Partnership is a collaborative regional framework to support the testing and demonstration of $\mathrm{CO}_{2}$ sequestration technologies in the central interior of North America.

The PCOR Partnership project includes five performance tasks:

Task 1 - Project Management, Reporting, and Technical Outreach

Task 2 - Identification and Resolution of Technology Deployment Issues

Task 3 - Public Perception and Outreach

Task 4 - Characterization of Regional Opportunities

Task 5 - Technology Selection and Action Plans 


\section{PCOR Partnership}

\section{Partners:}

is University of North Dakota Energy \& Environmental Research Center (EERC)

- Alberta Department of Environment

- Alberta Energy and Utilities Board

- Alberta Energy Research Institute

- Amerada Hess Corporation

- Basin Electric Power Cooperative

- Bechtel Corporation

- Center for Energy \& Economic Development - Minnesota Pollution Control Agency

- Chicago Climate Exchange

- Dakota Gasification Company

- Ducks Unlimited Canada

- Eagle Operating, Inc.

- Encore Acquisition Company

- Environment Canada

- Excelsior Energy, Inc.

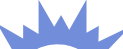

NETL
- Fischer Oil and Gas, Inc.

- Great Northern Power Development

- Great River Energy

- Interstate Oil and Gas Compact Commission (IOGCC)

- Kiewit Mining Group

- Lignite Energy Counci

- Manitoba Hydro

- Minnkota Power

- Montana-Dakota Utilities Co.

- Montana Department of Environmental Quality

- Montana Public Service Commission

- Natural Resources Trust

- Nexant, Inc.

- North Dakota Department of Health

- North Dakota Geological Survey

Saskatchewan

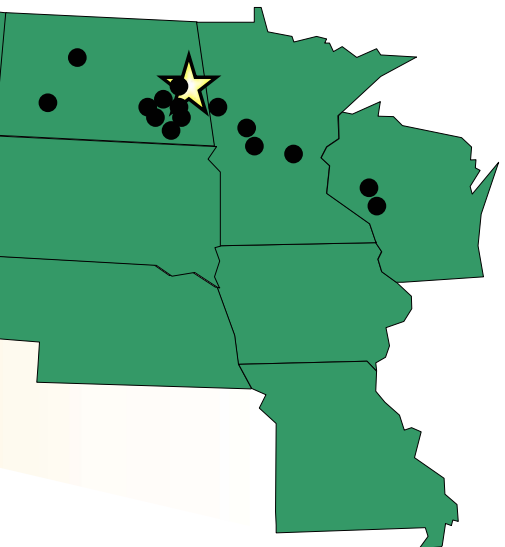

- North Dakota Industrial Commission (NDIC) Oil and Gas Division

- NDIC Research, Development, and Marketing Program

- North Dakota Petroleum Council

- North Dakota State University (NDSU)

- Otter Tail Power Company

- Petroleum Technology Research Centre

- Petroleum Technology Transfer Counci

- Prairie Public Television

- SaskPower

- Saskatchewan Industry and Resources

- Tesoro Refinery

- University of Regina

- U.S. Geological Survey - Northern Prairie Wildlife Research Center

- Western Governors’ Association

- Xcel Energy
Region Covered:

Iowa

Minnesota

Missouri

Montana

Nebraska

North Dakota

South Dakota

Wisconsin

Wyoming

Alberta

Manitoba

Saskatchewan 


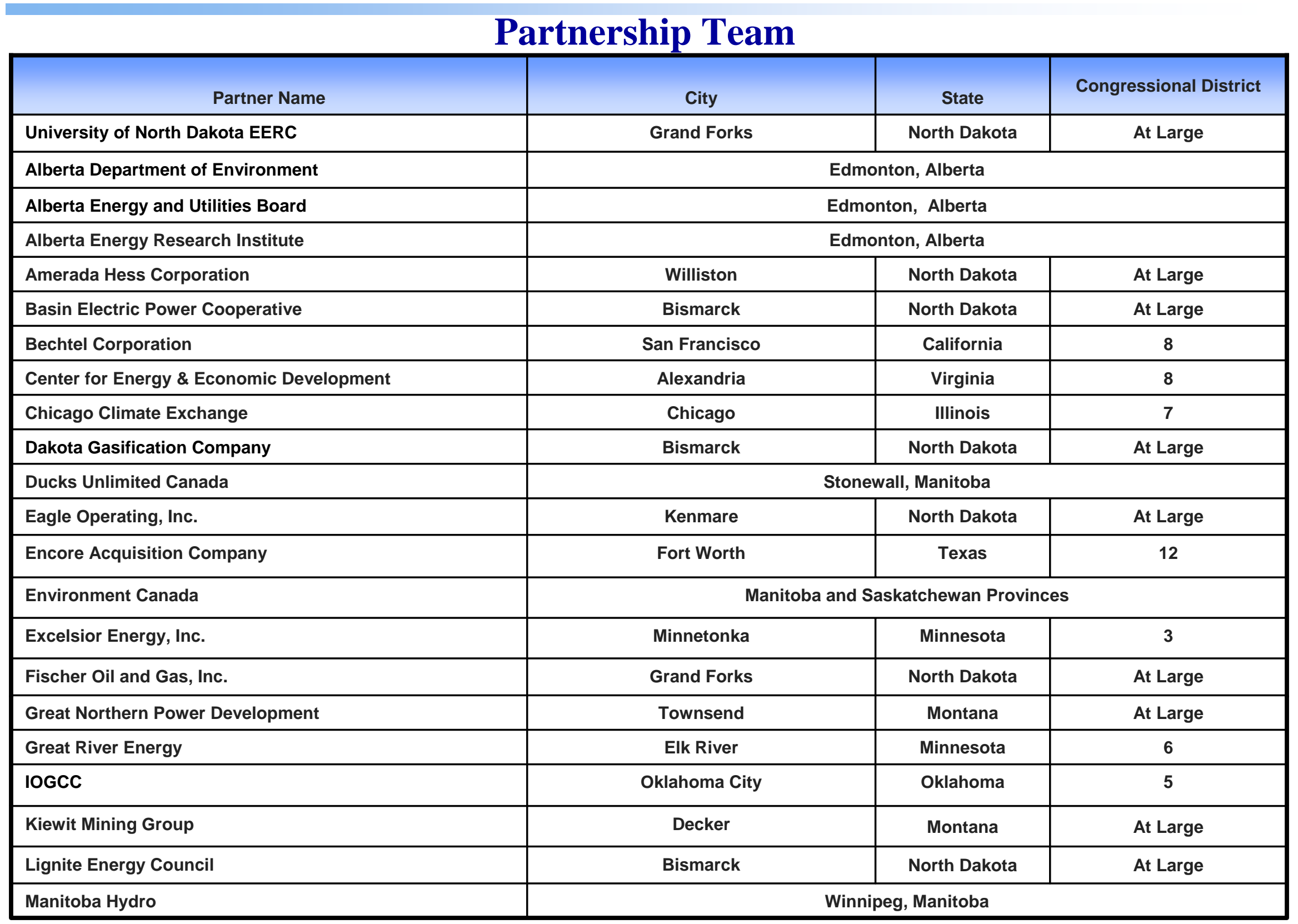




\begin{tabular}{|c|c|c|c|}
\hline Minnesota Pollution Control Agency & St. Paul & Minnesota & 4 \\
\hline Minnkota Power & Duluth & Minnesota & 8 \\
\hline Montana-Dakota Utilities Co. & Bismarck & North Dakota & At Large \\
\hline Montana Department of Environmental Quality & Helena & Montana & At Large \\
\hline Montana Public Service Commission & Helena & Montana & At Large \\
\hline Nexant, Inc. & San Francisco & California & 8 \\
\hline North Dakota Department of Health & Bismarck & North Dakota & At Large \\
\hline North Dakota Geological Survey & Bismarck & North Dakota & At Large \\
\hline NDIC Oil and Gas Division & Bismarck & North Dakota & At Large \\
\hline NDIC Research, Development and Marketing Program & Bismarck & North Dakota & At Large \\
\hline Petroleum Technology Research Centre & \multicolumn{3}{|c|}{ Regina, Saskatchewan } \\
\hline Petroleum Technology Transfer Council & Houston & Texas & 7 \\
\hline Prairie Public Television & Fargo & North Dakota & At Large \\
\hline SaskPower & \multicolumn{3}{|c|}{ Regina, Saskatchewan } \\
\hline Saskatchewan Industry and Resources & \multicolumn{3}{|c|}{ Regina, Saskatchewan } \\
\hline Tesoro Refinery & Mandan & North Dakota & At Large \\
\hline University of Regina & \multicolumn{3}{|c|}{ Regina, Saskatchewan } \\
\hline U.S. Geological Survey - Northern Prairie Wildlife Research Center & Jamestown & North Dakota & At Large \\
\hline Western Governors Association & Denver & Colorado & 1 \\
\hline Xcel Energy & Golden & Colorado & 7 \\
\hline
\end{tabular}




\section{Partnership Principals}

- Principal Investigator: Ed Steadman, EERC

- Task Leaders

- Task 1 - Management and Reporting - Ed Steadman

- Task 2 - Technology Deployment - John Harju and Lisa Botnen

- Task 3 - Public Outreach - Dan Daly

- Task 4 - Sources, Sinks, and Infrastructure - Jim Sorensen

- Task 5 - Modeling - Melanie Jensen

- Information Management System - Erin O'Leary

- NETL Project Manager: John Litynski 


\section{Budget}

\begin{tabular}{|c|c|c|c|c|c|}
\hline $\begin{array}{c}\text { Start } \\
\text { Date }\end{array}$ & $\begin{array}{c}\text { End } \\
\text { Date }\end{array}$ & $\begin{array}{c}\text { Government } \\
\text { Cost }\end{array}$ & $\begin{array}{c}\text { Performer } \\
\text { Cost }\end{array}$ & Total Cost & $\begin{array}{c}\text { Cost } \\
\text { Share }\end{array}$ \\
\hline $9 / 30 / 03$ & $9 / 30 / 05$ & $\$ 2,455,164$ & $\$ 843,063$ & $\$ 3,298,227$ & $25.6 \%$ \\
\hline
\end{tabular}

- U.S. Department of Energy (DOE) Costs to Date: $\$ 2,065,069$

- Cost Share to Date: $\$ 542,298$ 


\section{Highlights of Progress to Date}

- Task 1 - Management and Reporting

Presented at and/or participated in the following meetings:

- 2005 International Water Conference, Winnipeg, Manitoba (April).

- Carbon Sequestration Leadership Forum Stakeholder Briefing, Alexandria, Virginia (May).

- Fourth Annual Conference on Carbon Capture and Separation, Alexandria, Virginia (May). 


\section{Highlights of Progress to Date (cont.)}

- Task 2 - Technology Deployment

- Further development of measurement, mitigation, and verification strategies for potential geologic and terrestrial sequestration opportunities in the PCOR Partnership region.

- Finalized the topical report entitled "Deployment Issues Related to Geologic $\mathrm{CO}_{2}$ Sequestration in the PCOR Partnership Region."

- Continued preparation of draft Phase II action plan. 


\section{Highlights of Progress to Date (cont.)}

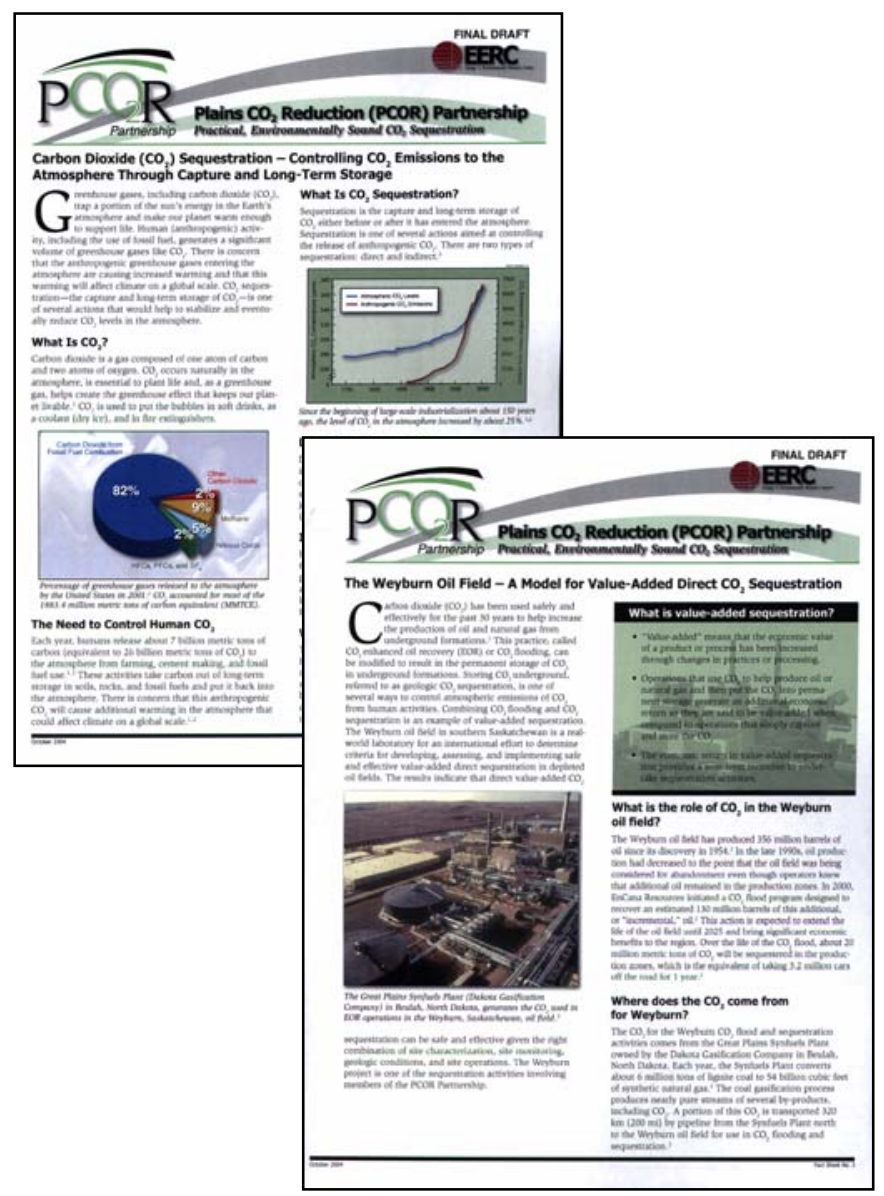

- Task 3 - Public Outreach

- Fact Sheet No. 2 (sequestration background) and Fact Sheet No. 3 (Weyburn project) finalized and sent for NETL review.

- Updated the public Web site.

- Focus groups held in mid-April in Williston, North Dakota, topical report completed in June 2005.

- Sequestration newspaper articles completed, distributed, and run in numerous regional newspapers.

- Input to the Regional Carbon Sequestration Program (RCSP) outreach paper for the May 2005 Alexandria Conference and to planning for the fall 2005 Programmatic Environmental Impact Statement (PEIS) hearings in the region. 


\section{Highlights of Progress to Date (cont.)}

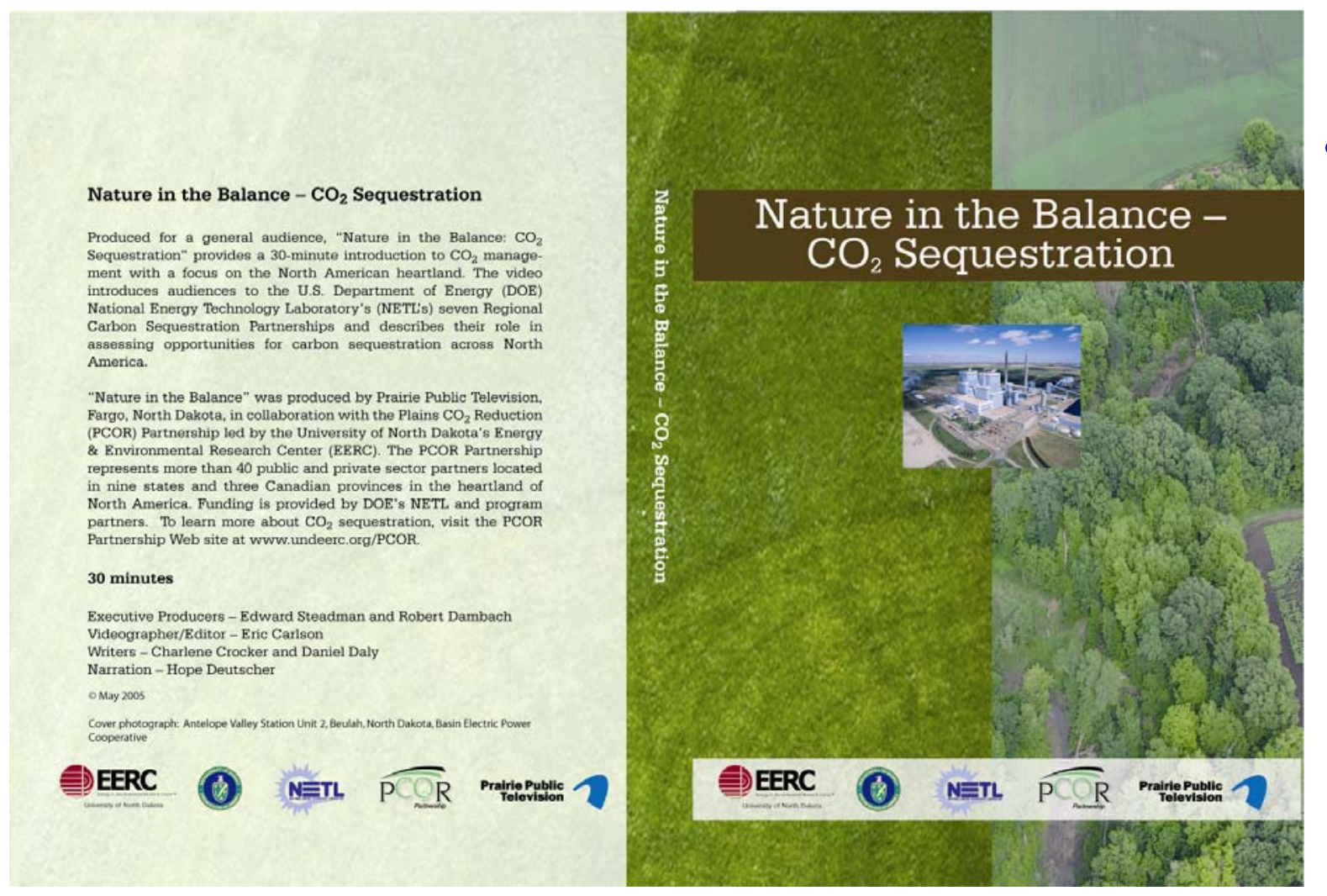

- Task 3 - Public Outreach (cont.)

- Video ("Nature in the Balance") editing, closed-captioning, DVD cover printing, and DVD production completed; video broadcast on PPTV on May 12, 2005. 


\section{Highlights of Progress to Date (cont.)}

- Task 4 - Sources, Sinks, and Infrastructure

- Source data for all states and provinces in the region have been collected and compiled into the Geographic Information System (GIS) database.

- Reconnaissance-level estimates of $\mathrm{CO}_{2}$ storage capacity of selected oil fields in all states and the provinces of Saskatchewan and Manitoba have been developed. $\mathrm{CO}_{2}$ capacity has been estimated for over 1500 oil fields in the PCOR Partnership region.

- Reconnaissance-level estimates of $\mathrm{CO}_{2}$ storage capacity have been developed for the Anderson-Wyodak coal seam of the Wyoming portion of the Powder River Basin and the Harmon coal seam of the Williston Basin.

- Reconnaissance-level estimates of $\mathrm{CO}_{2}$ storage capacity for the Madison Group and the Cretaceous System saline aquifers have been developed.

- Completed the "Carbon Separation and Capture" topical report in June 2005.

- Prepared the " $\mathrm{CO}_{2}$ Source Characterization of the PCOR Partnership Region" topical report.

- Prepared topical reports on the $\mathrm{CO}_{2}$ sequestration potential of selected oil fields, coal seams, and saline aquifers within the PCOR Partnership region.

- Prepared topical reports on the geology of the Williston Basin as it relates to $\mathrm{CO}_{2}$ sequestration. 


\section{Highlights of Progress to Date (cont.)}

- Task 4 - Sources, Sinks, and Infrastructure (cont.)

- Status of source characterization data

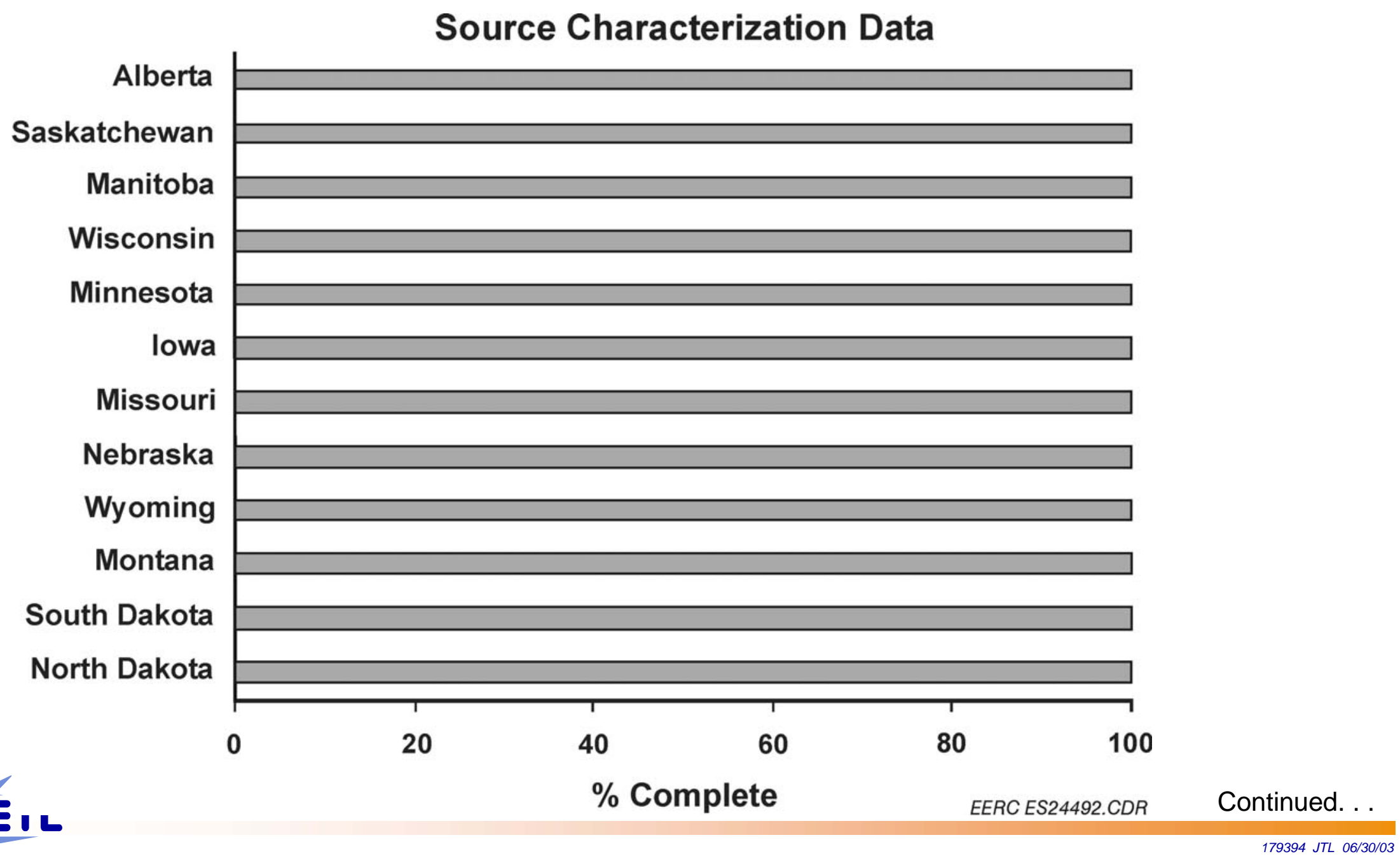




\section{Highlights of Progress to Date (cont.)}

- Task 4 - Sources, Sinks, and Infrastructure (cont.)

- Status of terrestrial sink characterization data

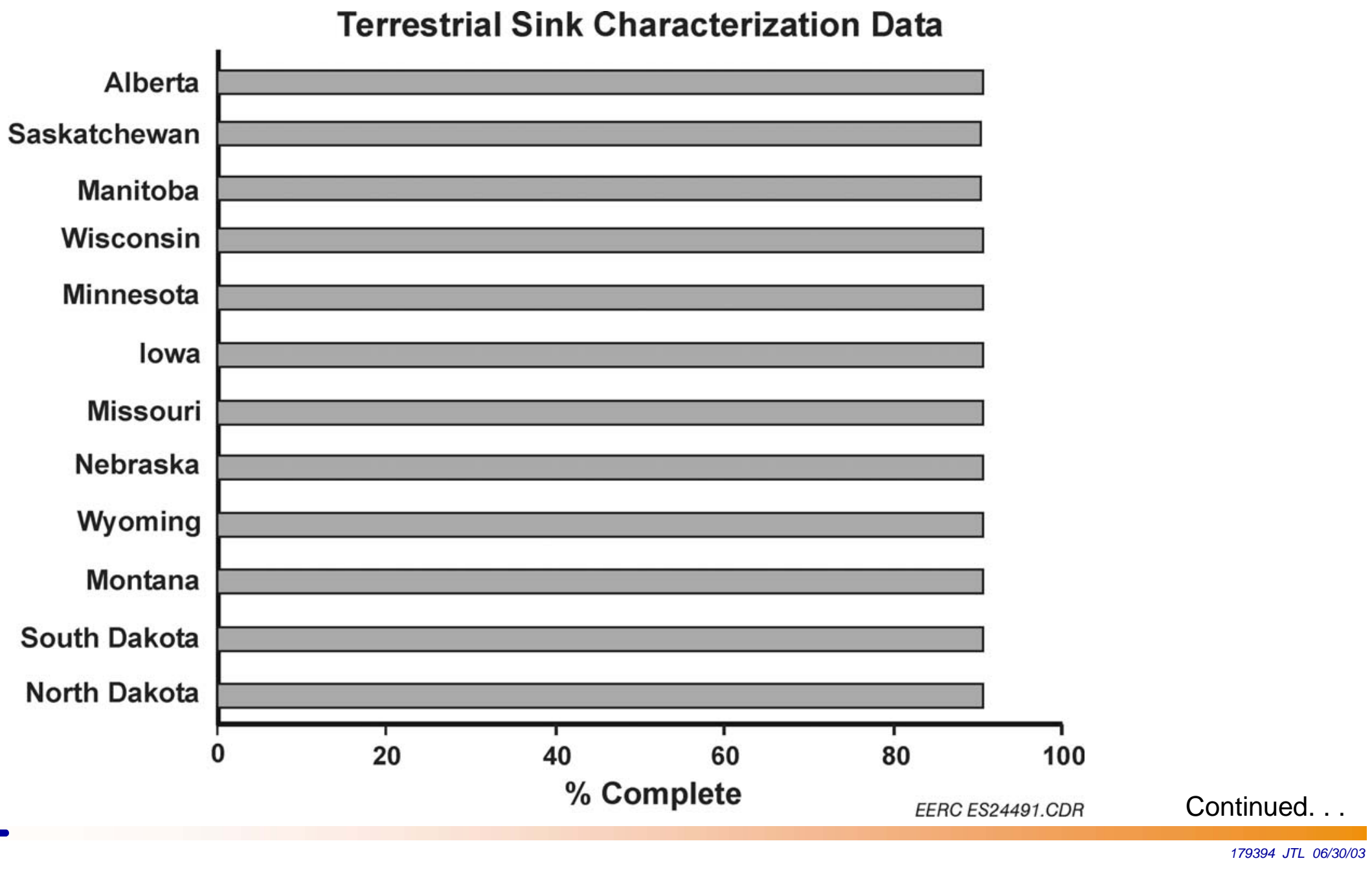




\section{Highlights of Progress to Date (cont.)}

- Task 4 - Sources, Sinks, and Infrastructure (cont.)

- Status of geological sink characterization data

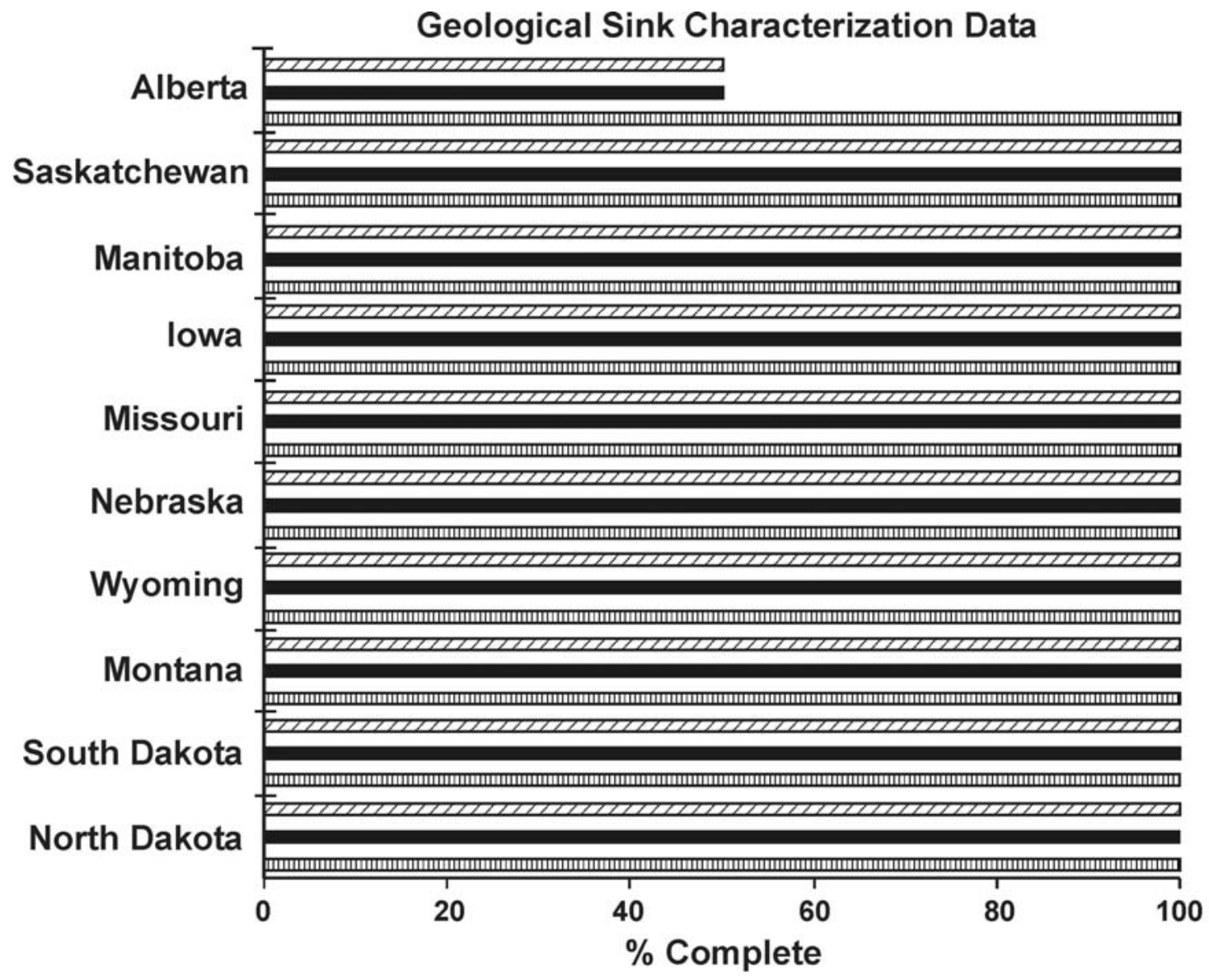

Formations

एבa Brine

Coal

血血 Petroleum

EERC ES24490.CDR

Continued. . . 


\section{Highlights of Progress to Date (cont.)}

- Information Management System - New Features

Save Bookmark: Saves map at current extent and layer settings to Favorites folder for retrieval at a later date.

Pool Report: Summarized variables for $\mathrm{CO}_{2}$ estimations now reported at the top of the pool report.

\begin{tabular}{|c|c|c|c|c|c|c|c|}
\hline EPCOR Partnership De & cision Support System - Micro & ft Internet Explorer & & & & & a $x$ \\
\hline File Edit View Fo & Siter Buffalo - Microsoft Internet & splorer & & & $-|\square| x \mid$ & & 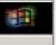 \\
\hline wack $\rightarrow \cdots$ & File Edit View Favorites & Tools Help & & & क⿻ & & \\
\hline Address & $\leftarrow$ Back - $\Rightarrow+\infty$ 에 쇼 & Q Search 㭡Favor & 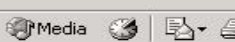 & 国 & & $\nabla \| \mathrm{Li}$ & Links \\
\hline Plains $\mathrm{CO}_{2}$ & The reference for each po & Tpertains to the en & set of reservolr (pool) & ta unless otherw/se indicated. & $\Delta$ & hetadat & \\
\hline Overview Map & Group & Formation & Sub Formation & Reference & & & \\
\hline Legend/Layer & - & Red River & & $\begin{array}{l}\text { SD Oil and Gas Production } \\
\text { Summary (2004) }\end{array}$ & & $\nabla$ & \\
\hline Zoom In & & & & & & & \\
\hline Zoom Dut & - CO2 Capacity Estimatio & & & & & & \\
\hline Full Extent & Value not originally report & & & & & & \\
\hline Last Extent & Parameter & value & Units & Additional Reference & & & \\
\hline Pan & Est. $\mathrm{CO} 2100 \%$ Capacity: & $69,321,334$ & tons & $\mathrm{CO} 2$ Sequestration Calculations & & & \\
\hline & $\begin{array}{l}\text { Est.CO2 } 100 \% \text { Capacity } \\
\text { volume: }\end{array}$ & $1,130,631$ & MMcf & CO2 Sequestration Calculations & & & \\
\hline $\begin{array}{l}\text { Select } \\
\text { Buffer }\end{array}$ & $\begin{array}{l}\text { Est. EOR CO2 100\% } \\
\text { Capacity: }\end{array}$ & & tons & CO2 Sequestration Calculations & & & \\
\hline $\begin{array}{l}\text { clear } \\
\text { selection } \\
\end{array}$ & $\begin{array}{l}\text { Est. EOR CO2 } 100 \% \\
\text { Capacity Volume: }\end{array}$ & & MMcf & $\mathrm{CO} 2$ Sequestration Calculations & & & \\
\hline & Surface Area: & 84,770 & acres & & & & \\
\hline & $\begin{array}{l}\begin{array}{l}\text { Average Pay Thickness } \\
\text { (ft): }\end{array} \\
\end{array}$ & 15 & & & & La & -1 \\
\hline Active Layer: Oil a & Average Porosity $(\%)$ : & 13 & & & & & \\
\hline $\begin{array}{l}\text { Oil and Gas } \\
\text { Field Name }\end{array}$ & Density: & 38.509 & $\mathrm{lbs} / \mathrm{t}^{3}$ & & & 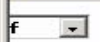 & 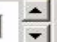 \\
\hline $\begin{array}{l}\text { Field Name } \\
\text { Total Record }\end{array}$ & $\begin{array}{l}\text { Average Reservoir } \\
\text { Temperature (F): }\end{array}$ & 201.6 & & $\mathrm{CO} 2$ Sequestration Calculations & & & - \\
\hline Unit Status: & $\begin{array}{l}\text { Initial Reservoir } \\
\text { Pressure: }\end{array}$ & 3,600 & & & & & \\
\hline Amor & $\begin{array}{l}\text { Average Initial Water } \\
\text { Saturation }(\%) \text { : }\end{array}$ & 50 & & $\mathrm{CO} 2$ Sequestration Calculations & & & \\
\hline $\begin{array}{l}\text { Amor South Red River } \\
\text { Unit }\end{array}$ & Original Oil in Place: & & & & & & \\
\hline Ash & & & & & & & \\
\hline Austin & + Reservoir Data & & & & -1 & & \\
\hline Buffalo & Done & & & & & & $=$ \\
\hline (]) Map: $-213918.14,65$ & 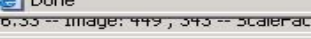 & & & 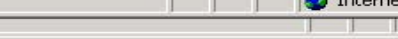 & प्साप्रा & & \\
\hline
\end{tabular}




\section{Highlights of Progress to Date (cont.)}

- Task 5 - Modeling

- The costs of retrofitting existing PCOR Partnership lignite-fired power plants with either amine scrubbing or oxygen combustion technologies were estimated. Capture and avoided costs were estimated to be $\$ 23 /$ ton $\mathrm{CO}_{2}$ and $\$ 35 /$ ton $\mathrm{CO}_{2}$, respectively, for amine scrubbing and $\$ 32 /$ ton $\mathrm{CO}_{2}$ and $\$ 55 /$ ton $\mathrm{CO}_{2}$ for oxygen combustion. The information was included in the "Carbon Separation and Capture" topical report.

- Details about the region's $\mathrm{CO}_{2}$ sources were gathered from the modeling spreadsheets and used to prepare the " $\mathrm{CO}_{2}$ Source Characterization of the PCOR Partnership Region" topical report.

- Preliminary economic estimations were begun for the important regional strategies that have been proposed for demonstration during Phase II. 


\section{Project Tasks and Status}

\begin{tabular}{|c|c|c|}
\hline Activity & Description & Status \\
\hline 1 & Negotiations and contract award. & Completed \\
\hline 2 & $\begin{array}{l}\text { Informational monthly meetings of the task } \\
\text { leaders. }\end{array}$ & Ongoing \\
\hline 3 & $\begin{array}{l}\text { Informational monthly meetings of the } \\
\text { "whole" (to include an informal presentation). }\end{array}$ & Ongoing \\
\hline 4 & $\begin{array}{l}\text { DOE quarterly reports and PowerPoint } \\
\text { update (quarterly). }\end{array}$ & Ongoing \\
\hline 5 & $\begin{array}{l}\text { Technical fact sheets on regional sources, } \\
\text { sinks, and candidate sequestration projects. }\end{array}$ & As-needed basis \\
\hline 6 & Annual carbon sequestration conference. & Completed \\
\hline 7 & Advisory committee meeting. & Meeting held October 14-15, 2004 \\
\hline 8 & $\begin{array}{l}\text { Advisory meeting comments/statements (to } \\
\text { be sent approximately one month after } \\
\text { meetings). }\end{array}$ & Ongoing \\
\hline 9 & All meeting and publicly presented materials. & As-needed basis \\
\hline 10 & $\begin{array}{l}\text { DOE Regional Carbon Sequestration } \\
\text { Partnership meetings. }\end{array}$ & Future activity \\
\hline
\end{tabular}




\section{Project Tasks and Status (cont.)}

\begin{tabular}{|c|l|l|}
\hline \multicolumn{2}{|l|}{ Task 2 - Technology Deployment } \\
\hline Activity & Description & Status \\
\hline 1 & Establish working group. & Completed \\
\hline 2 & $\begin{array}{l}\text { Obtain relevant regulations and permitting } \\
\text { requirements. }\end{array}$ & Completed \\
\hline 3 & $\begin{array}{l}\text { Review ecosystem studies; assess } \\
\text { environmental impacts. }\end{array}$ & Completed \\
\hline 4 & $\begin{array}{l}\text { Identify monitoring technologies and existing } \\
\text { verification plans. }\end{array}$ & Completed \\
\hline 5 & Develop verification strategy. & In progress \\
\hline 6 & $\begin{array}{l}\text { Develop preliminary input for action plan for } \\
\text { Phase II. }\end{array}$ & Completed \\
\hline 7 & $\begin{array}{l}\text { Facilitate preparation of draft Phase II action } \\
\text { plan. }\end{array}$ & Completed \\
\hline
\end{tabular}




\section{Project Tasks and Status (cont.)}

\begin{tabular}{|c|c|c|}
\hline Activity & Description & Status \\
\hline \multicolumn{3}{|c|}{ Working Group } \\
\hline 1 & Working group contact list. & Completed \\
\hline 2 & Outreach/education plan DRAFT. & Completed \\
\hline 3 & $\begin{array}{l}\text { Meeting/conference call (outreach working } \\
\text { group). }\end{array}$ & See Activity 5 \\
\hline 4 & Outreach/education plan FINAL. & In progress \\
\hline 5 & $\begin{array}{l}\text { Meeting (coincident with fall PCOR } \\
\text { Partnership meeting). }\end{array}$ & $\begin{array}{l}\text { Informal discussions at the PCOR Partnership meeting and } \\
\text { provided materials to select partners for review }\end{array}$ \\
\hline \multicolumn{3}{|l|}{ Web Site } \\
\hline 1 & Initial. & Completed \\
\hline 2 & Expanded. & Future activity \\
\hline \multicolumn{3}{|c|}{ Fact Sheets } \\
\hline 1 & PCOR Partnership description. & Completed \\
\hline 2 & Weyburn project. & Draft final (in review at NETL) \\
\hline 3 & Sequestration basics. & Draft final (in review at NETL) \\
\hline 4 & PCOR Partnership sources/sinks indirect. & Replaced by other products \\
\hline 5 & PCOR Partnership sources/sinks direct. & Replaced by other products \\
\hline
\end{tabular}




\section{Project Tasks and Status (cont.)}

\begin{tabular}{|c|l|l|}
\hline \multicolumn{2}{|l|}{ Task $3-$ Public Outreach (cont.) } & \multicolumn{2}{l|}{ Status } \\
\hline Activity & Description & \multicolumn{2}{l|}{} \\
\hline Middle School Education Activities & In progress \\
\hline 1 & $\begin{array}{l}\text { Inventory available curriculum and regional } \\
\text { training sessions. }\end{array}$ & In progress \\
\hline 2 & Obtain middle school curricula. & In progress \\
\hline 3 & Curricula outreach. & In progress \\
\hline 4 & $\begin{array}{l}\text { Decisions on other school outreach } \\
\text { opportunities. }\end{array}$ & $\begin{array}{l}\text { Completed (video editing, closed-captioning, DVD cover } \\
\text { design, and DVD production; broadcast on PPTV on May 12, } \\
\text { 2005); DVD will be distributed to partners, interviewees, and } \\
\text { select groups next quarter }\end{array}$ \\
\hline Public Information Campaign & $\begin{array}{l}\text { 30-minute Prairie Public Television (PPTV) } \\
\text { video (Nature in the Balance - CO } 2 \\
\text { Sequestration). }\end{array}$ & $\begin{array}{l}\text { Completed (three articles, distributed to regional papers and } \\
\text { run in select regional papers in early May 2005) }\end{array}$ \\
\hline 2 & $\begin{array}{l}\text { Five-article series on sequestration in major } \\
\text { regional newspapers (changed to three } \\
\text { articles series). }\end{array}$ & $\begin{array}{l}\text { Completed (focus groups held in mid-April in Williston, North } \\
\text { Dakota; report completed in June 2005) }\end{array}$ \\
\hline 3 & \begin{tabular}{l} 
Assessment of public knowledge. \\
\hline
\end{tabular}
\end{tabular}




\section{Project Tasks and Status (cont.)}

\begin{tabular}{|c|c|c|}
\hline \multicolumn{3}{|c|}{ Task Management and Support } \\
\hline \multicolumn{3}{|c|}{ Source Characterization } \\
\hline 1 & Acquire existing databases. & All states and Canadian provinces complete \\
\hline 3 & Data entry into PCOR Partnership databases. & Complete \\
\hline \multicolumn{3}{|c|}{ Infrastructure Characterization } \\
\hline 1 & Acquire existing databases. & In progress \\
\hline 2 & Data collection and entry. & In progress \\
\hline 2 & Data evaluation and reduction. & All states, Manitoba, Saskatchewan complete, Alberta in progress \\
\hline 3 & Data entry into PCOR Partnership databases. & All states, Manitoba, Saskatchewan complete, Alberta in progress \\
\hline 4 & $\begin{array}{l}\text { Field experiments at NDSU Hettinger Research } \\
\text { Extension Center (HREC). }\end{array}$ & In progress \\
\hline 5 & Soil carbon testing. & In progress \\
\hline 6 & Farm economic simulation model. & In progress \\
\hline 7 & Carbon sequestration in wetlands. & In progress \\
\hline
\end{tabular}

Continued. . . 


\section{Project Tasks and Status (cont.)}

\begin{tabular}{|c|l|l|}
\hline \multicolumn{2}{|l|}{ Information Management System } \\
\hline Task & Description & Status \\
\hline 1 & $\begin{array}{l}\text { Create foundation for GIS application and } \\
\text { database storage. }\end{array}$ & Completed \\
\hline 2 & $\begin{array}{l}\text { Create and populate databases. } \\
- \text { Define fields and data types. }\end{array}$ & Completed \\
\hline 3 & $\begin{array}{l}\text { Refine GIS Web site. } \\
- \text { Ability to view detailed characterization } \\
\text { information. } \\
- \text { Interactive features for analysis. }\end{array}$ & In progress \\
\hline
\end{tabular}




\section{Project Tasks and Status (cont.)}

\begin{tabular}{|c|l|l|}
\hline \multicolumn{2}{|l|}{ Task 5 - Modeling } \\
\hline Task & Description & Status \\
\hline 1 & $\begin{array}{l}\text { Draft of model variables (sources, sinks, and } \\
\text { infrastructure). }\end{array}$ & Completed \\
\hline 2 & Second draft of model. & Completed \\
\hline 3 & $\begin{array}{l}\text { Development of preliminary dataset for } \\
\text { testing. }\end{array}$ & Completed \\
\hline 4 & Alpha version of model. & Completed \\
\hline 5 & $\begin{array}{l}\text { Completion of model assessment of primary } \\
\text { action plans/alpha. }\end{array}$ & Completed \\
\hline 6 & Beta version of model. & Completed \\
\hline 7 & $\begin{array}{l}\text { Completion of model assessment of primary } \\
\text { action plans/beta. }\end{array}$ & Completed \\
\hline 8 & Final model results for DOE action plans. & Action plans are in progress \\
\hline
\end{tabular}




\section{Project Milestones}

\begin{tabular}{|c|c|c|}
\hline Milestone & Description & Status \\
\hline \multicolumn{3}{|c|}{ Management, Reporting, and Technical Outreach } \\
\hline 1 & Negotiate and award contract. & Completed \\
\hline 2 & Final report. & Future activity \\
\hline \multicolumn{3}{|c|}{ Technology Deployment Issues } \\
\hline 1 & Detailed work plan. & Completed \\
\hline 2 & Final task report. & In progress \\
\hline 3 & Input for scenario selection/action plans. & In progress \\
\hline \multicolumn{3}{|c|}{ Public Outreach } \\
\hline 1 & Detailed work plan. & Completed \\
\hline 2 & Middle school education materials. & In progress \\
\hline 3 & 30-minute general video. & Completed \\
\hline 4 & 10-minute technology videos. & (work plan revised, no longer required) \\
\hline \multicolumn{3}{|c|}{ Regional Characterization } \\
\hline 1 & Detailed work plan. & Completed \\
\hline 2 & Final task report. & In Progress \\
\hline \multicolumn{3}{|c|}{ Data Management, Scenario Selection, and Action Plans } \\
\hline 1 & Detailed work plan. & Completed \\
\hline 2 & Scenario screening. & Completed \\
\hline 3 & Scenario modeling. & Completed \\
\hline 4 & Scenario action plans. & In progress \\
\hline
\end{tabular}




\section{Project Recognition}

\section{Meetings/Conferences}

- 2005 International Water Conference, Winnipeg, Manitoba (April).

- 13th Williston Basin Petroleum Conference, Regina, Saskatchewan, (April).

- "New Natural Gas," Interstate Oil and Gas Compact Commission Midyear Issues Summit, Anchorage, Alaska (May).

- Carbon Sequestration Leadership Forum Stakeholder Briefing, Alexandria, Virginia (May).

- Fourth Annual Conference on Carbon Capture and Separation, Alexandria, Virginia (May).

- Meeting with North Dakota Petroleum Council (NDPC), Bismarck, North Dakota (June).

- American Association of Petroleum Geologists 2005 Annual Convention Exploring Energy Systems, Calgary, Alberta (June).

- Meeting with Ducks Unlimited, Inc., U.S. Geological Survey, and Ducks Unlimited Canada, Bismarck, North Dakota (July). 


\section{Project Deliverables}

\begin{tabular}{|c|c|c|}
\hline Deliverable & Description & Status \\
\hline \multicolumn{3}{|c|}{ Management, Reporting, and Technical Outreach } \\
\hline 1 & DOE management/PCOR Partnership project review meeting & Ongoing \\
\hline 2 & Advisory group meetings & Ongoing \\
\hline 3 & PCOR Partnership Web site & Completed \\
\hline 4 & Attendance/presentations at technical meetings & Ongoing \\
\hline 5 & Technical outreach Web pages & In progress \\
\hline 6 & PCOR Partnership meetings/workshops & Completed \\
\hline 7 & Quarterly reports & Ongoing \\
\hline \multicolumn{3}{|c|}{ Technology Deployment Issues } \\
\hline 1 & Workshop background/products & Completed \\
\hline \multicolumn{3}{|c|}{ Public Outreach } \\
\hline 1 & Workshop materials & Completed \\
\hline 2 & Focus group results & Completed \\
\hline 3 & Public outreach Web pages & Completed \\
\hline \multicolumn{3}{|c|}{ Regional Characterization } \\
\hline 1 & Workshop materials & In progress \\
\hline 2 & Information assessment & In progress \\
\hline 3 & Criteria and inputs for scenario selection/action plans & In progress \\
\hline \multicolumn{3}{|c|}{ Data Management, Scenario, Selection and Action Plans } \\
\hline 1 & Workshop materials & Completed \\
\hline 2 & Populated relational/GIS database & Completed \\
\hline
\end{tabular}




\section{Next Steps}

Task 1 - Management and Reporting

- Continue overall project management and reporting.

- Seek additional partnership opportunities where appropriate.

- Complete Phase I products per schedule provided to DOE project manager.

\section{Task 2 - Technology Deployment}

- Complete development of monitoring, measurement, and verification strategies for potential geologic and terrestrial sequestration options in the PCOR Partnership region. 


\section{Next Steps (cont.)}

\section{Task 3 - Public Outreach}

- Continue participation in RCSP Outreach Working Group conference calls.

- Distribute DVDs of "Nature in the Balance" to partners, participants, and other select groups.

- Continue efforts to enable the broadcast of "Nature in the Balance" in other Public Television market areas in the PCOR Partnership region and in other partnership regions.

- Complete education contact list, education forum list, curriculum packet, and list of candidate outreach opportunities.

- Completed topical report on focus group activities (June 2005).

- Update Web site as appropriate. 


\section{Next Steps (cont.)}

Task 4 - Sources, Sinks, and Infrastructure

- Incorporate sink-related databases for Alberta into GIS Web site.

- Develop sequestration potential estimates for key geological sinks in Alberta.

- Obtain infrastructure databases and map files.

- Summarize baseline data from HREC plots.

- Prepare conceptual design of economic analysis model for terrestrial sequestration.

- Finalize remaining sink-related topical reports.

- Initiate development of sink-related portion of project final report. 


\section{Next Steps (cont.)}

Task 5 - Modeling

- Complete preliminary economics for important regional strategies to rank them relative to each other.

- Prepare a topical report describing the matching/screening protocol, the results of the beta check, the preliminary economic calculations of the sequestration process as applied to the most promising regional strategies, and the final regional results.

\section{Information Management Systems}

- Input Alberta data.

- Program terrestrial database and GIS layers.

- Create Atlas. 


\section{Upcoming Issues}

Task 1 - Management and Reporting

- None

Task 2 - Technology Deployment

- None

Task 3 - Public Outreach

- Pursue opportunities to broadcast "Nature in the Balance" in other public television markets 


\section{Upcoming Issues (cont.)}

Task 4 - Sources, Sinks, and Infrastructure

- Sources of pipeline data and maps - commercial vendors and government agencies have different restrictions that must be dealt with; data from government agencies would be best, but may need formal request to come from DOE.

Task 5 - Modeling

- None

Information Management Systems

- None 